\title{
Life design counselling effects on the career adaptability of learners in a selective independent school setting
}

\author{
Jacobus G. Maree* and Claire Symington \\ Faculty of Education, University of Pretoria, 0001, Pretoria, South Africa \\ *Corresponding author email: Kobus.Maree@up.ac.za
}

\begin{abstract}
This collective case study applied life design counselling to augment the career adaptability of learners in a South African independent school setting. Five purposively selected learners attending Grade 11 (age range: 16-18) completed eight group-based life design counselling sessions. Data on their career adaptability pre- and post-intervention were gathered from sessional notes. The data were thematically analysed. Following the intervention the participants displayed improved career adaptability as evidenced by their demonstrated efforts to address aspects related to career concern, control, curiosity and confidence. Life design counselling appeared to have a positive effect on the career adaptability of learners in an independent school setting.
\end{abstract}

Keywords: adaptability, adolescents, career counselling, groups, independent school-based interventions; life design, social-constructionism

In the $21^{\text {st }}$ century, careers have become more personal; consequently existing theories of career counselling and assessment can no longer account for the post-modern focus on contexts or how the individual adapts to various social settings (Cochran, 1997). This insight has prompted career counselling practices to increasingly focus on constructing "lives through work and relationships" (Richardson, 2012, p. 191). This shift in the career counselling approach implies that school career counselling practices now have to adopt narrative models and self-construction methods of counselling (Savickas, 2007). Savickas (2008) regards the career construction model, particularly the concept of adaptation, to be most suited to helping adolescents negotiate and plan their anticipated career trajectory. Career adaptation requires an individual to adjust and transition "from [grade to grade], from school to work, from job to job and from occupation to occupation" (Savickas, 2008, p. 2). These transitions reveal five main coping behaviours (i.e. orientation, exploration, establishment, management and disengagement) that recur in the form of mini-cycles as an individual transitions from one job to the next, whilst at the same time completing or negotiating career stages of the so-called 'maxi-cycle' (Savickas, 2011a).

The extent to which school career counselling could make use of life design approaches needs to be explored. There are more studies in public schools than in independent schools that have considered career counselling interventions. In the South African context, these school contexts differ in terms of mission and values as well as the resource portfolio to support career counselling programs. A distinction should be noted between the two categories of schools, as recognised by the South African Schools Act (SASA) (ISASA, 1999; RSA, 1996), namely: public and independent. A public school is controlled by the state, whereas an independent school is privately owned.

Career counselling in South Africa, in both public and independent schools, is incorporated in the compulsory learning area Life Orientation, which was designed to replace the educational system's career dedicated programme, previously known as Guidance. In the revised curriculum, career education is represented as one of the four learning outcomes incorporated in the Life Orientation statement (The Department of Education, 2003).The Department of Education (2003) further strives to facilitate Life Orientation as a means of equipping learners with personal management skills necessary for success in additional and higher education, and in adult life. A relevant assessment standard for this learning area suggests that a learner should be able to "display an awareness of trends and demands in the job market, as well as the need for lifelong learning" (Department of Education, 2003).

Although Hofmeyr and Lee (2002) concluded that "independent schools are rich and poor, religious and secular, urban and rural, big and small, traditional and alternative", the participants in our study were from a higher priced (with annual school fees exceeding R70 000) independent school. This arguably suggests that the above-mentioned efforts may receive greater attention since financial support and social class appear to provide access to more career advancing opportunities (Lent, Brown, Talleyrand, McPartland, Davis, \& Chopra 2002). Blustein, Chaves, Diemer, Gallagher, Marshall, \& Sirin (2002) were also able to ascertain that in comparison to lower-income families, individuals from high-income families generated greater personal satisfaction from work and benefited more directly from the availability of external resources. In general, they also displayed a higher level of career adaptability and seemed to be in a better position to enjoy more meaningful and self-fulfilling careers.

\section{Life Design Counselling}

Sliep (2007) focuses on the value of sharing life stories with others in an educational setting. Participants or peers become a "witnessing community" when others openly share their life story with them. Weingarten (2003) supports this notion and adds that a collective approach to sharing stories allows for the witnessing of self through others. Welch (1990) has also noticed the benefits of this 
type of intervention and mentions that "mutual transformation occurs when there is the power of empathy and compassion ... and strength in the solidarity of listening to others". When learners share stories with one another, it can have a therapeutic effect. The storyteller and author must however feel sufficiently comfortable with the audience to engage in reflective thought. The shared engagement of storytelling and listening that occurs between the teller and the audience holds a beneficial reward for both parties. It also places the audience member in the privileged position of witnessing and being inspired by the way the storyteller takes an active approach in authorising his/her stories (Sliep, 2007). Savickas, Nota, Rossier, Dauwalder, Duarte, Guichard, ... \& Van Vianen (2009) were of the view that while it is important to understand how people decide on a career, it may also be beneficial to ask the question: "How might individuals best design their own lives in the human society in which they live?" Life design counselling is premised on the concepts of identity (self), narratability of identity (story) and intentionality (meaningful action) (Lent, 2012). Narratability focuses on assisting clients in forming and narrating a congruent story in an effort to create an improved understanding of their life themes, vocational personality and adaptability resources (Savickas et al., 2009). It also contributes to an increased possibility of achieving their expectations by allowing them to become more aware of their salient life roles and domains in relation to their future expectations. Counsellors are also encouraged to introduce their clients to the process of intentionality which requires them to reflect and revise their thoughts in order to focus their minds on meaning making instead of choice (Richardson, Meade, Rosbruch, Vescio, Price, \& Cordero, 2009).

The above theoretical shifts shaped the development of a three-step life design counselling process starting with the construction of a story, followed by placing the story into a larger story and concluding with the co-construction of a future story (Savickas, 2011b). This often involves scripting a new story that integrates the old problem within a new story. Post-intervention, the client is encouraged to participate in activities or new experiences that allow him/ her to actualise his/her possible self.

Career construction theory, which forms the basis for life design, relies on the premise that people construct their career trajectories by attaching meaning to their career experiences. This meaning is imbedded in various themes that join together to form a recognisable plot which creates the basis of a life story about a person's career identity. Counsellors and clients are therefore encouraged to construct stories that allow clients to actively overcome what they have passively endured as they relive a specific issue repetitively in the hope that they will become more apt at resolving it (Savickas, 2011a). Social constructivism focuses on the relationships between people and their social environment, suggesting that knowledge is historically and culturally specific, and apparent in interactions, processes and social practices (Young \& Collins, 2004). Since people are inclined to construct their identities through stories that eventually start to reflect notable patterns or themes, identity can be storied and experiences can be constructed. The person consequently begins to rely on these stories to locate or describe his/her attributes (Del Corso \& Rehfuss, 2011). Identity therefore serves as the connecting link between the person and the various contexts he/she is immersed in. This process demands self-awareness but also reflection. Career identity on the other hand, involves the "practice of articulating, performing and negotiating identity positions in narrating career decisions" (LaPointe, 2010).

\section{Group intervention}

Savickas and Porfeli (2012) suggest that a group discussion focused on the processes involved in decision-making may be very useful for improving career adaptability. Kuijpers, Meijers, and Gundy (2010) stressed the value of dialogue between students as a reflective activity, because, like Mair (1989), they also believe that it is "not just what is told and how it is told, it is the very act of telling, the speaking itself, which seems to matter". Di Fabio and Maree (2012) proposed that the larger audience is likely to re-enforce the client's process of meaning making because he/she is able to integrate the collective feedback into his/ her construction of Self. The numerous advantages of group-based counselling include offering the client an opportunity to perform a dual role of being both an actor and an audience member - thus contributing to more insightful and enriched decision-making. When life stories are shared with others in an educational setting, participants or peers become a "witnessing community" (Sliep, 2007).

\section{Goal of the study}

This study sought to apply life design counselling to Grade 11 learners from an independent school. The question that guided our study was the following: What is the effect of life designing counselling on the career adaptability of learners in an independent school context?

\section{Method}

\section{Research design}

A multi-method, explorative, descriptive, collective case study was used (Symington, 2014). The use of a collective case study easily lent itself to the in-depth investigation of the unique characteristics of the life design programme which the participants and the group sessions gathered over the intended research period (Neuman, 1997). This method therefore seemed to provide ample opportunity for the constructs of life-design counselling and career adaptability to be studied from multiple perspectives and within the context in which they occur (Creswell, 2003).

\section{Participants and setting}

Five purposively selected learners were the study participants (see Table 1 for demographics).

Table 1. Description of the participants

\begin{tabular}{lllll}
\hline Participant & Gender & Age & $\begin{array}{l}\text { Home } \\
\text { language }\end{array}$ & Race \\
\hline 1 & Male & 16 & English & Indian \\
2 & Male & 17 & English & Coloured \\
3 & Female & 16 & Afrikaans & White \\
4 & Female & 17 & English & Black (Zulu) \\
5 & Male & 18 & English & White \\
\hline
\end{tabular}


The ethos of the independent school used in our study is based on Christian principles. Currently, 1200 learners are enrolled ranging from Grade 000-12. With regards to career education, the school offers annual career assessments to all Grade 9 learners to assist with subject choice. An educational psychologist is permanently available on site to provide psychological counselling. Career education modules are offered as part of the Life-Orientation curriculum and focus on the development of career specific skills, such as compiling a curriculum vitae; preparing for a job interview and applying to tertiary institutions. This specific module is offered during one of the three terms and is compulsory for all learners up to Grade 12 .

\section{Case description}

Participant 1's responses to the interview depicted him as a loyal and dependable person. He also displayed a strong obligation towards his family and was committed to achieving his pre-established academic and career goals. He appeared to experience a large degree of anxiety with regards to possible failure and/or not being able to pursue a career in medicine. Participant 2's responses showed him to be a very driven and decisive person who presented as a natural leader. He developed contingency plans to secure his envisioned future and set great store by financial success. As a child, he experienced an unstable home environment. He demonstrated a comprehensive understanding of the career market and was only interested in careers that were financially lucrative. In her presentation, participant 3 seemed to be a person who values knowledge and competency. She seemed interested in understanding the world around her in a very strategic manner and appeared dedicated to finding solutions to problems. Initially she had made very little effort to obtain career information and reported that she was uncertain of her intended course of study, apart from knowing that she is committed towards enrolling for a general course at a tertiary institution after completing Grade 12. Participant 4, in her responses, seemed like a person interested in caring about others' opinions, particularly her parents'. She demonstrated a good understanding of others' feelings and came across as a very caring and sensitive person. She had made little effort to explore her personal career options and instead conceded to letting her parents make decisions for her. She appeared to battle with expressing her own needs and asserting herself. Participant 5's responses depicted him as someone who attached high value to justice and fairness. His home circumstances reflected a strained relationship with his parents. He also battles with a learning difficulty which seemed to initially limit his career exploration and confidence.

\section{Data gathering}

Five data sources were used for this study, including (i) transcribed co-constructed discussions recorded during group life design sessions; (ii) sessional observations; (iii) transcribed individual interviews; (iv) a research journal; and (v) participant journals.

\section{Summary of the life design intervention across the eight sessions}

Eight life design counselling sessions were conducted (see Table 2). The sessions were held in a classroom at the school. The duration of these sessions was approximately 45-60 minutes and offered over a period of four months. The sessions are briefly described in Table 2.

\section{Data analysis}

Our data analysis process involved five distinct steps: obtaining a holistic image by making a study of all the available data; generating themes and compiling topics from the data; organising the data into a systematic code list that served to compare topics, avoid duplication and arrange the topics in order of importance; encoding the topics and putting them to the test; and verifying our organisational system by analysing groups of data and then compiling categories. Recurring and significant themes were identified and topics were organised into discrete categories. The various subcategories and categories were grouped together under overarching themes.

\section{Ethical issues}

Permission to conduct the study was obtained from the Ethics Committee of the Faculty of Education of the University of Pretoria. Informed assent was obtained from the participants, who were informed about the purpose and consequences of participation. Privacy, confidentiality and anonymity were observed, and measures to ensure the participants' wellbeing and protection from harm were implemented throughout the study. Parents of the learners provided their written consent.

\section{Results}

Nine main themes emerged from the analysis of the narrative data (see Table 3).

These themes are elaborated below, focusing on the post-intervention outcomes.

\section{Theme 1: Responses related to career adaptability and the related sub-skills \\ Career concern}

Lower-end career concern was initially displayed by the two female participants (Participants 3 and 4) in that they demonstrated an overall lack of planning and indecision towards designing their future career trajectories, as suggested by the following example:

Then I didn't do the future part, because the future will come. Whatever happens, happens. (Participant 3 in session 6 whilst discussing her life line).

Although the other three participants' responses reflected high-end career concern at the start of the intervention, the life design counselling programme nonetheless seemed to complement their already existing efforts to pursue their chosen career trajectories, as suggested by the following statement:

I want to make decisions now, so that I don't drop out and waste six years. (Participant 2 during his pre-interview). 
Table 2. Description of intervention

\begin{tabular}{|c|c|c|}
\hline \multirow{2}{*}{ Session } & Process & \multirow{2}{*}{ Expected Outcomes } \\
\hline & Participants ... & \\
\hline Orientation & $\begin{array}{l}\text { were given an opportunity to discuss their } \\
\text { specific career problem, define their expectations, } \\
\text { describe their role models, and share their three } \\
\text { earliest memories. }\end{array}$ & $\begin{array}{l}\text { The problem and its main context are recognised. } \\
\text { Describing their role models is seen as a means } \\
\text { of reflecting their self-conception which serves } \\
\text { to create a template for finding solutions. } \\
\text { Recollecting their three earliest memories reveals } \\
\text { their central preoccupation; life lessons learned in } \\
\text { childhood and a possible plan of action to manage } \\
\text { their present career scenario. }\end{array}$ \\
\hline Exploration & $\begin{array}{l}\text { explored their current SIFs, drew a family } \\
\text { genogram; listed their favourite reading material; } \\
\text { shared their favourite story; and talked about } \\
\text { their hobbies and special skills/talents. }\end{array}$ & $\begin{array}{l}\text { These activities were intended to explore the } \\
\text { participants' interests and preferred settings as } \\
\text { well as identifying possible resources that could } \\
\text { assist them in addressing their central life concern. } \\
\text { This contributes to the participant experiencing a } \\
\text { better understanding of him/herself and how he/she } \\
\text { manages to balance Self and function in the salient } \\
\text { domain }\end{array}$ \\
\hline Reflection & $\begin{array}{l}\text { were invited to discuss their biggest success and } \\
\text { failure experiences in addition to drafting their } \\
\text { life line and story. }\end{array}$ & $\begin{array}{l}\text { These activities were aimed at widening their } \\
\text { perspectives. }\end{array}$ \\
\hline 4-7. Individual restorying & $\begin{array}{l}\text { were helped to place their existing problems } \\
\text { within their revised story. }\end{array}$ & $\begin{array}{l}\text { That which was implicit is now explicit and } \\
\text { obvious. The story can now be re-authored in a } \\
\text { refreshing way. }\end{array}$ \\
\hline 6-7. Group restorying & $\begin{array}{l}\text { were encouraging to participate in group } \\
\text { discussions about the emerging themes generated } \\
\text { from the previous sessions. }\end{array}$ & $\begin{array}{l}\text { That which was implicit is now explicit and } \\
\text { obvious. The story can now be re-authored in a } \\
\text { refreshing way. }\end{array}$ \\
\hline 8. Identity life design & $\begin{array}{l}\text { were helped to identify and plan activities that } \\
\text { may assist the participants to actualise their } \\
\text { own identities, and to reflect on their experience } \\
\text { of life design, group work and the various } \\
\text { post-modern career counselling activities they } \\
\text { had completed. }\end{array}$ & $\begin{array}{l}\text { The last session was designed to identify and } \\
\text { plan activities that may assist the participants in } \\
\text { actualising their own identities. A synthesis is } \\
\text { created between the old and new, when the client } \\
\text { is able to commit to some role and identity. It is } \\
\text { expected that the participants can now move closer } \\
\text { to future scenarios. }\end{array}$ \\
\hline
\end{tabular}

Table 3. Summary of the identified themes and subthemes

\begin{tabular}{|c|c|c|}
\hline \multirow{2}{*}{$\begin{array}{l}\text { Theme } \\
\text { number }\end{array}$} & Pre-intervention theme & Post intervention theme \\
\hline & Pre-intervention status: Participants ... & Theme \\
\hline 1 & $\begin{array}{l}\text { gave insufficient evidence of being able to adapt to change in general. More particularly, two } \\
\text { female participants displayed lower-end career concern and a lack of curiosity. The three male } \\
\text { participants displayed higher levels of career concern, with two of them demonstrating high } \\
\text { career curiosity and control. }\end{array}$ & $\begin{array}{l}\text { Responses related to } \\
\text { career adaptability and } \\
\text { the related sub-skills }\end{array}$ \\
\hline 2 & $\begin{array}{l}\text { acknowledged to some extent that their parents contributed significantly to their future career } \\
\text { plans. One participant refused to incorporate their opinions in his career decisions. Another } \\
\text { participant was unable to assert her personal choice and insisted on pursuing a career suggested } \\
\text { by her parents. }\end{array}$ & $\begin{array}{l}\text { Family/significant } \\
\text { others' influences. }\end{array}$ \\
\hline 3 & $\begin{array}{l}\text { seemed rather fixated on the perceived importance of choosing a career that would enable } \\
\text { them to maintain their current financial wealth. The two male participants, in particular, had } \\
\text { disregarded their interests in an effort to secure lucrative job opportunities in a seemingly } \\
\text { competitive career market. }\end{array}$ & $\begin{array}{l}\text { Financial and economic } \\
\text { considerations. }\end{array}$ \\
\hline 4 & $\begin{array}{l}\text { were very concerned at the quick succession of time and attached significant importance } \\
\text { to achieving their goals without delay. They also seemed to experience difficulty with } \\
\text { time-management due to their busy schedules. }\end{array}$ & The value of time. \\
\hline 5 & $\begin{array}{l}\text { apart from one, appeared oblivious of the vital role of emotional intelligence in enabling them to } \\
\text { achieve in their chosen careers }\end{array}$ & $\begin{array}{l}\text { Components related to } \\
\text { Emotional Intelligence. }\end{array}$ \\
\hline 6 & $\begin{array}{l}\text { seemed to have worked through the previous developmental stages satisfactorily and were } \\
\text { now engaged in the process of exploring their identity and experimenting with their sense of } \\
\text { autonomy. }\end{array}$ & Adolescent development. \\
\hline 7 & $\begin{array}{l}\text { appeared acutely aware of the important role of various school-related factors in helping them } \\
\text { attain their career-related dreams, such as academic achievement, the role of extra-curricular } \\
\text { activities and various social aspects. }\end{array}$ & School life. \\
\hline 8 & $\begin{array}{l}\text { were largely unaware that childhood dreams played a pivotal role in co-determining the way in } \\
\text { which they would eventually choose careers and construct themselves }\end{array}$ & Childhood dreams. \\
\hline 9 & $\begin{array}{l}\text { displayed a distinct lack of awareness of what the changed approach to career counselling would } \\
\text { entail. }\end{array}$ & $\begin{array}{l}\text { Reflection on the } \\
\text { process of life design } \\
\text { counselling. }\end{array}$ \\
\hline
\end{tabular}




\section{Control}

The two female participants displayed lower-end career control in that their career planning behaviours were inhibited. Their uncertainty is reflected in their responses during session 1 when they requested assistance with career planning:

To prepare me for my career and everything involving my future (Participant 4)

and

If I know where I want to go, I can start planning and stop stressing. (Participant 3).

Participant 2 appeared to battle the most with making career decisions independently of others, as suggested by the following statement:

I just do what they [parents] tell me. I really ... I don't want to go to [university's name omitted], but my mom told me that I am. (Participant 4 during session 4).

Another participant (Participant 1) initially demonstrated some lower-end career control in that his sense of personal mastery and belief in his competencies and abilities had made him second-guess his choices.

\section{Curiosity}

Although all five of the participants appeared to hold rather realistic views of the future world of work, they differed in their efforts to obtain career-related information. Initially the two female participants' (Participants 3 and 4) responses reflected the poor effort that they had made to arm themselves with occupational knowledge. During the weekly sessions Participant 3 explained her emerging curiosity as part of her life story chapters:

Now ... I am still like a worm because I'm still not ready and I'm still not grown up yet. So, I'm still on my path to find what I am. (Participant 3 during session 8)

The same appeared to apply to Participant 5 who initially seemed reluctant to explore alternatives based on his self-efficacy beliefs:

I haven't really set myself up for being anything else besides a teacher, because I don't think I will do fairly well in any other sort of environment (Participant 5 during his pre-interview)

\section{Career confidence}

Career confidence was especially noted in the participants' reflections offered with regards to their earliest recollections, life-mottos as well as the life story chapters. Three participants (Participants 2, 3 and 5) demonstrated career confidence as early as during their pre-interviews. The afore-mentioned participants' responses reflected self-assurance with regard to implementing their career plans and negotiating change in the future. Participant 2's reflection on his lifeline illustrated his capacity to manage change as noted in a discussion about his parents' divorce:

Basically, you can throw anything at me and I will be able to handle it (Participant 2 during his post-interview whilst reflecting on his life-line)

Similarly, Participant 3 was able to acknowledge the influence of past events by commenting:

It always turns out for the best and there is always a reason for everything. (Participant 3 during her post-interview)
The participants also became increasingly aware of their strengths and weaknesses, as suggested by Participant 1 's response:

I think it helps you to learn from your mistakes and figure out your skills and see what you are good at and what you are not good at and it can actually benefit you in the future. (Participant 1 during session 2 reflecting on his success and failure experiences)

Theme 2: The influence of significant others on the participants' career trajectory.

Regarding the influence of significant others on the participants' career trajectory, it appeared as though the role of their parents contributed significantly to their future career plans. The participants, apart from one, valued their parents' opinion and experienced a commitment towards honouring their parents' investment in their education, as implied by the following response:

So in order to make my family happy, I have to give them the luxuries they want and provide for them, just like my parents have done for me. And I think that that is only fair, because my parents have put me in good schools - crazy amounts of money for this type of schooling. (Participant 2 during his post-interview)

This sentiment was also reflected by Participant 5 during his post-interview:

The way I see it, they [the other participants] have made their parents their role models and they have to live up to their parents' standards and what their parents think. From the very beginning, my parents have said: 'Be what you want, we don't really care - we will support you'. (Participant 5 during his post-interview)

One participant (Participant 4) demonstrated a strong commitment towards pursuing a career path determined by her parents.

\section{Theme 3: Financial and economic considerations}

The first aspect involved the value that the participants attached to the financial wealth associated with their current and future lifestyles. One participant admired his role model because

... he is brilliant; he has money. (Participant 1 during

Session 7 whilst discussing his role model)

They were also intent on making use of the opportunities that they were given and consequently improving their chances of success by advancing their skill sets, exploring opportunities that would provide them with the best chance of success and achieving high academic results as suggested by the following example:

But, like now, I would try and make sure that I have something that other students don't have so that I can get in easier. (Participant 1 during session 6)

\section{Theme 4: The value of time}

The participants demonstrated a significant awareness of time's fleeting nature with one participant describing it as follows:

It's scary, because everything is happening so fast and I'm meant to change and know what I am doing, but ... it's all happening too fast. (Participant 3 during her pre-interview)

Four participants' responses also reflected efforts towards making the best use of their time, without any deviation from course, such as taking a gap year, which is seen 
as a waste of time. They seemed to view time as a means to an end and believed that the sooner one starts to put a plan in motion the sooner one is able to live the desired life.

\section{Theme 5: Components related to the construct of interpersonal skills intelligence (Bar-On, 2007)}

One participant in particular, reflected on the value of developing inter- and intrapersonal skills as follows:

In the beginning of our lives, we are basically taught emotions and how to use these sorts of things. That's very much like tools used in creating an art piece. You get to know when to use a pencil and when to use an eraser, when to change the type of lead. When to change the colour. (Participant 5 during his post-interview whilst describing his life story chapters)

Initially, Participant 4 appeared to battle the most with these skills. She recalled how she, as a child, had bumped and injured her head quite seriously:

The whole towel was covered in blood, and I don't remember crying at all and I don't remember making any fuss. Like, I don't remember making anything big out of it. Like my parents just took me to hospital and I just slept on their bed. (Participant 4 during session 2 whilst discussing her earliest recollection).

\section{Theme 6: Developmental tasks associated with adolescents}

Various sub-themes that emerged from the analysis of the qualitative data related well to the developmental tasks expected of adolescents. Based on Erikson's (1980) developmental phases, an adolescent is immersed in the task of establishing his/her identity - a process that one participant referred to as follows:

So you always keep thinking: who you were, what experiences happened and that ... it's just a time to sit back and have some self-time and self-thought. (Participant 5 during his pre-interview)

One participant acknowledged the role of identity in life-design by referring to it as follows:

I think because who you are and what you are kind of makes your path for you ... you strive to do and be true to who you are. (Participant 3 during her post-interview)

She was also able to identify strengths and characteristics with the eye on her future career needs, such as her ability to solve problems, as indicated by the following response:

I think careerwise, I would have to solve problems, because that is what I like. (Participant 3 during her post-interview)

In our study, life-design counselling appeared to illuminate and even challenge certain beliefs that the participants held about themselves and the world, as indicated by the following participant responses:

I have a few other talents... I have people listen to me - maybe some leadership qualities in me. (Participant 2 during session 2).

And

I know what they are all thinking... 'He's a sick and twisted child' (Participant 5 during session 2 after sharing his earliest recollection)

\section{Theme 7: School life}

Based on the participants' responses, all five of them were in agreement regarding the importance of completing a tertiary qualification. Examples of such responses are:

A kid can come out of Grade 12 and be a billionaire, but the statistics are very, very low. A kid needs to go to university, which I would say is a more reasonable and successful way of getting on with life. (Participant 5 during his pre-interview)

and:

Yes, I am going to go study ... definitely. It is not that I am being forced to, I want to study to accomplish something and know that I have that behind me ... having a degree is always something to fall back on, always something that supports me. (Participant 3 during her pre-interview)

\section{Theme 8: Childhood career ambitions}

Although the participants were reluctant to pursue these ambitions, their planned career trajectories, nonetheless, seemed to contain elements of their original ambitions as suggested by the following participant responses:

I see myself in medicine. Ever since, I was little - it was all I wanted to do. (Participant 1 during his pre-interview), and:

I very often get side-tracked with ... sort of childhood ideas - army, fire-fighting, ambulance work, community sort of stuff ... Because as a child, you are taught those are your heroes and you have to respect them. (Participant 5 during his pre-interview)

\section{Theme 9: Reflection on the life design counselling process}

Four participant responses suggested that this approach to career counselling was regarded as more favourable than the traditional career approach, largely due to the emphasis it places on acknowledging individuality and the role that co-constructed knowledge and context can play in a person's life design process. Examples of the afore-mentioned positive response to life design counselling include:

No, tests wouldn't work ... when you actually talk to someone and you converse with them, you can see how a person reacts - that is more effective, it gives you more of an understanding. (Participant 5 during his post-interview),

and:

I like this method, because it opened up my eyes to a lot more things about myself and about different careers that are personal to me and not just the factual things about what I should go and do. (Participant 3 during her post-interview)

All five participants seemed to enjoy working in a group together as shown by the following examples:

It is a good thing to say things out loud. I never say it aloud... and this morning in group was good. Especially hearing what they thought ... because I think I am invisible to everyone." (Participant 4's journal entry)

and:

I've always wanted an ideal sense of where I want to go in life, but it is always interesting to sort of see where other people are going and if I am going the right direction (Participant 5 during his post-interview)

Participant 2's responses suggest that she particularly enjoyed being familiar with the other participants in the group and highlighted the following: 
I feel like I got to know them even better. It felt good to talk about stuff. (Participant 4 during her post-interview)

The participants' involvement in group sessions also provided ample opportunity to reflect and comment on each other's shared life-design activities, as depicted by the following two examples:

He is very wise. Like he doesn't conform to society. He is an asset to the world in saying things from like a different perspective. (Participant 4 reflecting on Participant 5's completed life-design activities)

\section{Discussion}

These life design counselling activities appear to have contributed to an improvement in clients' displayed level of career concern, control, curiosity and confidence. From a developmental perspective, one of the main tasks associated with adolescence is an increased display of concern towards career exploration (Savickas, Passen, \& Jarjoura, 1988; Skorikov, 2007). Based on the participant responses from our study all five participants seemed to share Savickas' (1997) belief that career planning and exploration were imperative to career decision-making processes. Similar to Germeijs and Verschueren's (2011) study, the two female participants demonstrated greater signs of indecisiveness than the males and discussed the difficulty they were experiencing with regards to career indecision.

All five participants conceded that they felt apprehensive about the future. They consequently viewed the life design counselling programme as an opportunity to gain more certainty with regards to their future career plans and demonstrated an openness to consider possible alternatives to the existing ones, which relates to Creed, Fallon and Hood's (2009) finding that the improvement of career adaptability skills (with the focus on building competence and self-improvement) can serve as a means of reducing the immobilising effect of elevated career concerns on career decision-making and self-exploration. Savickas (2011a) suggested that clients are likely to benefit from stories that help them recall previous experiences involving change, as well as the resources that helped them cope with the related uncertainty. Similarly, Rottinghaus, Buelow, Matyja and Schneider (2012) observed that the use of life design activities is likely to enhance a person's coping abilities due to an improvement in his/her self-awareness and knowledge of career-related information.

The participants' responses suggest that the quality of family relationships were likely to influence their future life design (see also Kenny \& Bledsoe, 2005; Hirschi, 2009). Family values; the degree of parental control and interest, as well as particular events that occurred in the family (e.g. divorce and an attempted suicide) were discussed during the group activities and individual interviews. For instance, a participant reflected on how the quality of the relationship with her parents has affected her ability to act assertively and communicate openly with them about her future plans. A study by Young, Paseluikho, and Valach (1997) suggested that the emotional quality of the parent-child relationship is affected by whether they share similar or opposing constructions of the adolescent's anticipated career trajectories.
Several of the participants noted perceived parental influence as suggested by their desire to design lives that would be considered stable and financially secure. In particular, the participants expressed a desire to maintain a similar or better quality of life as compared to the one to which they had become accustomed. This finding is consistent with one by Ashby and Schoon (2012) who reported that career, family and wealth aspirations held at the age of sixteen had a significant bearing on a person's well-being and perception of success in later life. All five participants' responses subsequently demonstrated a commitment towards enrolling for their tertiary studies.

Successful management of career-related tasks is seen to contribute positively to an adolescent's level of career maturity, which enhances his/her ability to cope with the "psycho-social demands of transitions into working life" (Seifert, 1993, p. 355). Life design counselling with group sessions rendered positive outcomes. Thus, group-based career interventions are important for group interaction skills development to support reflective thinking (Santos, 2004). It is perhaps the very social support offered by the group setting that has helped the participants in our study "identify strengths and assets to overcome weaknesses, barriers and perceived deficits that constrain story development" (Campbell \& Ungar, 2004, p. 37).

Participant responses confirmed the usefulness of listening to multiple opinions as well as the power of the audience (see also Campbell \& Ungar, 2004; Kuijpers et al., 2010; Del Corso \& Briddick, in press). In our study the shared engagement of story-telling and listening that occurred between the participant/teller and the other group members/audience seemed to hold a beneficial reward for both parties, since participants could indeed witness and be inspired by their fellow participants' efforts to authorise their story (Di Fabio \& Maree, 2012).

\section{Limitations}

Further research initiatives are needed to substantiate the stability of our findings and to elaborate on the value of group-based life design counselling interventions aimed at increasing learners' career adaptability. The ideal would be to replicate the study with a larger group of diverse participants.

\section{Conclusion}

The overall responses from participants suggest that the life design counselling programme was well received. Group-based intervention further stimulated the co-construction of insights that could hopefully assist participants in their attempts at making meaning of their diverse life stories.

\section{References}

Ashby, J. S., \& Schoon, I. (2012). Living the dream? A qualitative retrospective study exploring the role of adolescent aspirations across the life span. Developmental Psychology, 48, 1694-1706.

Bar-On, R. (2007). How important is it to educate people to be emotionally intelligent, and can it be done? In: R. Bar-On., J. G. Maree, \& M. J. Elias (Eds.), Educating people to be emotionally intelligent (pp. 1-16). Johannesburg, South Africa: Heinemann Publishers. 
Blustein, D. L., Chaves, A. P., Diemer, M. A., Gallagher, L. A., Marshall, K. G., \& Sirin, S. (2002). Voices of the forgotten half: the role of social class in the school-to-work transition. Journal of Counselling Psychology, 49, 311-323.

Campbell, C., \& Ungar, M. (2004). Constructing a life that works: part 2, an approach to practice. The Career Development Quarterly, 53, 28-40.

Cochran, L (1997). Career Counselling: a narrative approach. Thousand Oaks, CA: Sage

Creed, P. A., Fallon, T., \& Hood, M. (2009). The relationship between career adaptability, person and situation variables, and career concerns in young adults. Journal of Vocational Behaviour, 74, 219-229.

Creswell, J. W. (2003). Research design: qualitative, quantitative and mixed methods approaches, 2nd ed. Thousand Oaks, CA: Sage

Del Corso, J., \& Rehfuss, M. C. (2011). The role of narrative in career construction theory. Journal of Vocational Behaviour, 79, 334-339.

Del Corso, J. J., \& Briddick, H. S. (in press). Using audience to foster self-narrative construction and career adaptability. In: P. J. Hartung, M. L. Savickas, \& W. B. Walsh. (Eds.), Handbook of Career Intervention: Vol 2. Applications (pp. 255-268). Washington, DC: American Psychological Association.

Department of Education. (2003). Revised National Curriculum statement: Grades 10-12 (General Statement): Life Orientation. Pretoria, South Africa: Government Printer.

Di Fabio, A., \& Maree, J. G. (2012). Group-based life design counselling in an Italian context. Journal of Vocational Behaviour, 80, 100-107.

Erikson, E. H. (1980). Identity and the life cycle (Vol. 1). New York, NY: WW Norton \& Company.

Germeijs, V., \& Verschueren, K. (2011). Indecisiveness and the big fiver personality factors: relationship and specificity. Personality and individual differences, 50, 1023-1028.

Hirschi, A. (2009). Career adaptability development in adolescence: multiple predictors and effect on sense of power and life satisfaction. Journal of Vocational Behaviour, 74, 145-155.

Hofmeyr, J. \& Lee, S. (2002). Demand for private education in South African schooling and higher education. Perspectives in Education, 20(4), 77-86.

Independent Schools' Association of Southern Africa (ISASA). (1999). Introduction to independent schooling. Retrieved from: http://www.isasa.org/content/view/306/176/

Kenny, M. E., \& Bledsoe, M. (2005). Career adaptability in context: the role of support, barriers and peer school beliefs. Journal of Vocational Behaviour, 66, 257-2732.

Kuijpers, M. A. C. T., Meijers, F., \& Gundy, C (2010). The relationship between learning environment and career competencies of students in vocational education. Journal of Vocational Behaviour, 78, 21-30.

LaPointe, K. (2010). Narrating career, positioning identity: career identity as a narrative practice. Journal of Vocational Behaviour, 77, 1-9.

Lent, R. W. (2012). Work and relationship: is vocational psychology on the eve of construction? The Counselling Psychologist, 40, 269-278.

Lent, R. W., Brown, S. D., Talleyrand, R., McPartland, E. B., Davis, T., \& Chopra, S. B. (2002). Career choice barriers, supports and coping strategies: college students' experiences. Journal of Vocational Behaviour, 60, 61-72.

Mair, M. (1989). Psychology as a discipline of discourse. BPS Psychotherapy Section Newsletter, 1-12.

Neuman, W.L. (1997). Social research methods: qualitative and quantitative approaches. 3rd ed. New York: Allyn and Bacon.

Republic of South Africa (RSA). (1996). South African Schools Act. Act No. 84 of 1996.

Richardson, M. S. (2012). Counselling for work and relationship. The Counselling Psychologist, 40, 425-433.
Richardson, M. S., Meade, P., Rosbruch, N., Vescio, C., Price, L., \& Cordero, A. (2009). Intentional and identity processes: a social constructionist investigation using student journals. Journal of Vocational Behaviour, 74, 63-74.

Rottinghaus, P. J., Buelow, K. L., Matyja, A., \& Schneider, M. R. (2012). The Career Futures Inventory - Revised: measuring dimensions of career adaptability. Journal of Career Assessment, 20, 123-139.

Santos, P. (2004). Career dilemmas in career counselling groups: theoretical and practical issues. Journal of Career Development, 31, 31-44.

Savickas, M. L. (1997). Career adaptability: an integrative construct for life-span, life-space theory. Career Development Quarterly, 45, 247-259.

Savickas, M. L. (2007). Prologue. In: J. G. Maree (Ed.). Shaping the story (pp. 1-3). Pretoria, South Africa: Van Schaik Publishers.

Savickas, M. L. (2008). Report on framework and follow-up studies. XXXXIX International Congress of Psychology. Berlin, Germany, 19 July 2008.

Savickas, M. L. (2011a). New questions for vocational psychology: premises, paradigms and perspectives. Journal of Career Assessment, 19, 251-258.

Savickas, M. L. (2011b). Career construction theory and practice. In: S. D. Brown, \& R. W. Lent (Eds.), Career Development and counselling: putting theory and research to work, 2nd ed. (pp. 147-186). Hoboken, NJ: Wiley

Savickas, M. L., Nota, L., Rossier, J., Dauwalder, J. P., Duarte, M. E., Guichard. J., ... \& Van Vianen, A. E. M. (2009). Life designing: A paradigm for career construction in the 21st century. Journal of Vocational Behaviour, 75, 239-250.

Savickas, M. L., \& Porfeli, E. J. (2012). Career Adapt-Abilities Scale: construction, reliability and measurement equivalence across 13 countries. Journal of Vocational Behaviour, 80, 661-673.

Savickas, M. L., Passen, A. J., \& Jarjoura, D. G. (1988). Career concern and coping as indicators of adult vocational development. Journal of Vocational Development, 33, 82-98.

Seifert, K. H. (1993). Improving prediction of career adjustment with measures of career development. Career Development Quarterly, 94, 353-367.

Skorikov, V. B (2007). Continuity in adolescent career preparation and its effects on judgement. Journal of Vocational Behaviour, 70, 8-24.

Sliep, Y. (2007). Waving a learning community by the telling, deconstructing and retelling of life stories. In: J.G. Maree (Ed.), Shaping the story (pp. 138-151). Pretoria, South Africa: Van Schaik Publishers.

Symington, C. (2014). The effect of life-design counselling on the career adaptability of learners in an independent school setting. Unpublished doctoral thesis, Pretoria, South Africa: University of Pretoria.

Weingarten, K. (2003). Common shock: witnessing violence every day: How we are harmed, how we can heal. New York, NY: Dutton.

Welch, S. (1990). A feminist ethic of risk. Minneapolis, MN Fortress Press.

Young, R. A., \& Collins, A. (2004). Introduction: constructivism and social constructionism in the career field. Journal of Vocational Behaviour, 64, 373-388.

Young, R. A., Paseluikho, M. A., \& Valach, L. (1997). The role of emotion in construction of career in parent-adolescent conversations. Journal of Counselling and Development, $76,36-44$ 